\title{
THE LEARNING STRATEGY OF ISLAMIC EDUCATION IN UPGRADE OF LEARNING QUALITY
}

\author{
Dinil Abrar Sulthani \\ Universitas Islam Jakarta \\ Jl. Balai Rakyat Utan Kayu No.64, Jakarta Timur, Jakarta 13120 \\ Email: dinil_umsb@yahoo.com \\ DOI: $10.29313 /$ tjpi.v6i1.2371
}

Accepted: April 10th, 2019. Approved: July 20th, 2017. Published: July 20th, 2017

\begin{abstract}
This study is attempted to reveal, analyze, and investigate the learning strategies practiced by the teachers of Islamic study in teaching the materials in Islamic senior high school of Al-Azhar 1 Jakarta. The instruments used in this study were 1) observation, 2) interview, and 3) documentation. The findings were elaborated into categorization, description, analysis, and recommendation. Based on the findings, the learning strategy applied in Islamic senior high school Al-Azhar 1 Jakarta is by selecting of learning strategies and then mixing them. The learning strategies were direct learning strategy, indirect learning strategy, interactive learning strategy, learning strategy through experience and independent learning strategy. Those strategies are the success factors of learning in the school, especially for Islamic study. Therefore, the teaching learning in Islamic Senior High School Al-Azhar 1 Jakarta needs to upgrade its quality and the teachers of Islamic Education should develop the various learning strategies.
\end{abstract}

Keywords: Learning Strategies, Teachers, and Learners.

\begin{abstract}
ABSTRAK
Penelitian ini dilakukan untuk mengungkap, menganalisis, dan menjelaskan strategi pembelajaran yang digunakan guru agama Islam dalam menyampaikan materi pelajaran di SMA Islam Al-Azhar 1 Jakarta. Instrumen yang digunakan dalam penelitian di lokasi penelitian yaitu 1) observasi, 2) wawancara, dan 3) studi dokumentasi. Data yang ditemukan di lokasi penelitian, selanjutnya penulis mengkategorisasi, mendeskripsikan, dan menganalisis, serta memberikan rekomendasi atas hasil yang ditemukan. Berdasarkan penelitian yang telah dilakukan bahwa strategi pembelajaran yang diterapkan di SMA Islam Al-Azhar 1 Jakarta adalah memilih dan menggabungkan beberapa strategi pembelajaran seperti; strategi pembelajaran langsung, strategi pembelajaran tidak langsung, strategi pembelajaran interaktif, strategi pembelajaran melalui pengalaman dan strategi pembelajaran mandiri. Strategi pembelajaran tersebut merupakan salah satu faktor keberbasilan pembelajaran di sekolah, secara khusus pelajaran agama Islam. Dengan demikian, pelaksanaan pembelajaran di SMA Islam Al-Azhar 1 Jakarta agar meningkatkan kualitasnya, dan guru P AI melakukan pengembangan strategi pembelajaran secara variatif.
\end{abstract}

Kata kunci: Strategi Pembelajaran, Guru, dan Peserta Didik. 


\section{INTRODUCTION}

The phenomenon of education is growing in now, that proper is attention for all. Especially for good government as far as small of civil society. The first, the education institute in Indonesia, especially for Institute of Islamic Education showed performance superior. However, it's not yet in all region. The conditions are not mistaken from education operate but to needs from government especially the ministry of religion for cooperative and attention objective conditions. So that, Institute of Islamic education can be felt on supporting for full facility and development program of the quality education.

And, the government must be attention to education institute so that its ability to developing and significant progress. A point of failure in the learning process is the inconsistent implementation of ruled. Therefore, an Islamic characteristic of the Institute of Islamic Education can always be to upgrade and implementing school management on consistent and innovative. The consistent for a learning rule will be producing learn and image of the quality institution.

For to measure and the quality value of Institution is observing a learn that implemented in the institution. A quality of institution must choose the best foundation that is a good learning. Because of the quality learn must be possession as for every institution in the period. Therefore, a quality institution with a good learning dependent on the teacher to teach the material.

The teacher will be just a good learning with used the learning strategies on precise, attractive method, and appropriate to needs for psychology students. A load of teacher became heavier because of the hand of teachers shaped a future generation of students. If the learning is going to good then hope for fixed out is good too. However, if the teacher is not a professional learning, more then transfer process of knowledge is not maximal.
The second, The teacher is a prime pivot for changing in a lesson, a guidance and transferring knowledge to students in institutions. Therefore, the teacher must be measuring for to find a new variant in transferring information to students. That is giving to learning on fact and quality. As like used learning strategies, learning method, or learning technique.

The next, to teach of the teacher is an urgent interest for students because they are giving on information in the lesson. And they usually see how the act of teacher in the material presented. A transfer process of knowledge must be a correlation with moral and attitude showed for the student, so they understand the ability of lesson and to become of the teacher is an inspiration of life.

More than, for the teacher who is not upgrading competition will be lost for self, students, and institutions. To lower of teacher competitions will be to influence on the late grade of institution quality in pedagogic, especially for Islamic education institution. The problems will be a bad image of Islamic institution. As a competition, recruiting students and certainly parents for to send to school in an Islamic institution. As well as alumni who are lower to religion implementation in life.

Therefore, the teacher on learn implementation must be spirit priority in the quality upgrade. That is using a learning strategy on the right, especially for Islamic lesson then Islamic teacher education must be competent to describe of material in class. The use of strategies will direct students to starts and get used to religion knowledge so that implementation in life.

The third, The students are a future generation of the nation. Therefore, the teacher must be directing and guiding students on optimal to attitude and knowledge forming as a model to walk in life and giving an advantage to civil society. The students are a type of effort to upgrade human resources for the better. Therefore, that precise if students to given of 
information and knowledge in the lesson. Indonesia government obliged nine of years learning with free courses. That is serious of government in preparing for a gold generation with maximal. So that student gets a high education in Indonesia. Hope for The regulation can be implemented on equally to twelve educational for students in Indonesia. So that, Indonesia go forward and compete with other countries.

From the description, it is clear that students are the most important part of the population in this country. They must be nurturing, guiding and given facilities to potential completed and fulfill rights of education. However, it has recently become a bad spectacle on the national stage, that many of the behaviors of students are beyond normal limits. The phenomenon is a bad record for Indonesia's future progress. Cases of students is a problem that must be immediately provided solutions for handling. All elements of society must participate with together in maintaining national resilience by providing supervision and education for students to stay on track.

The cases that arise example the students to perform actions not reflect the good personality, such as brawl, smoking, even perform immoral acts. KPAI Data (Indonesian Child Protection Commission) in 2014 mentions there are 1713 cases related to children (students/children), including; Clusters of Religion and Culture (51 cases), Education (157 cases), and Pornography and Napza (65 cases) (www.kpai.go.id). This data is still in the iceberg view of the iceberg, could be a case that is held by a new child care agency on the upper level only.

This kind of incident will continue if it is not found a solution, that is part of educational portrait that recently rampant in Indonesia. Therefore, to will be massive movement, especially educational institute forming learning based on morals and strengthening of value, so as to minimize the problems will be not desirable in the future. The institution of education is maximizing properly. That is a way to reduce the declining education portrait.

The Fourth, the material of learning is one of the most important that must exist in learning. This component should be well organized and mapped to suit the learning objectives. The preparation of this material must be by the agreement of educational operate based on curriculum applicable in Indonesia. Therefore, the material of learning should be easily understood and absorbed by the students and become capital in continuing higher education and practice in their daily life.

The material content is not well presented it will be burdensome for students to absorb the knowledge provided. In particular, in Islamic studies, material content provided by teachers should be pursued on phenomena or stories that occur in real life and also exemplified in everyday attitudes. The exemplification of Islamic values will minimize the gap between the content of the material with the teacher's personality, which ultimately students will be able to understand and actualizing the knowledge of religion obtained.

The Fifth, the teacher in giving the material of learning, must be pointing out ways during the teaching process called learning strategy. After that, the teacher can choose the right method of delivery steps in using the method in the delivery of teaching. The Teacher ignorance of the use of instructional strategies, methods and teaching techniques appropriately will have an impact on the low achievement of learning. Because the size of optimizing learning is to use all available resources so that the knowledge transfer process can be done well to the students. Strategies, methods, and techniques should be a consideration for teachers if they want to optimize learning for the realization of education and students who are smart, personable and useful for the nation.

From the fifth explanation of the phenomenon above, gives a determine that there is a need for serious efforts in 
improving the quality of learning in Islamic educational institutions. One effort that can be done is to strengthen the teachers learning strategy in delivering the teaching materials in the classroom. And also, teachers should have appropriate and measurable learning strategies in the learning process of every educational institution, specifically Islamic educational institutions. The learning strategy is related to PAI lessons, with the understanding that the focus of this research will reveal the learning strategies used by the PAI teacher in delivering the teaching materials.

The author sees the importance of achieving learning outcomes in SMA Islam Al-Azhar 1 Jakarta. The aims to knowing the conditions and learning situations applied in the school, especially, a learning strategy used by PAI teachers. Selection of Islamic High School Al-Azhar 1 Jakarta because excellent school performance, arena competitions, art contest and alumni of the school can continue in universities State and overseas

(http://www.smaalazhar1.sch.id/v1/home) . The success is sustained by the spirit of teachers in delivering teaching materials with appropriate learning strategies. The study was conducted thoroughly, revealing data and information from several parties, both from the headmaster, students, and teachers of PAI itself. It is hoped that this research will be able to move the learning condition that occurs in the research location on paper so that it can be analysis and modification as an example for other Islamic education institutions.

The technique of data collecting is activating by a natural setting, that is a process of teaching and learning of Islamic education conducted by teacher and students. To obtain valid findings and interpretations, there are several steps taken by researchers. These steps are to extend the presence of researchers in the study sites, deepening the observations used triangulation (Sugiyono, 2009: 241). The first, the authors make observations about the phenomena that occur in teaching and learning process in SMA Islam Al-Azhar 1 Jakarta. The observing these phenomena will make it easier for writers to find learning strategies used by teachers of Islamic Education (S.Margono, 2007: 158).

Secondly, the authors conducted interviews orally in face to face with headmaster, teachers of PAI, and high school students of Islam Al-Azhar 1 Jakarta for more detailed and complex data collection (Nana Syaodih Sukmadinata, 2012: 216). And Third, the author will do the tracking of documents related to the history of standing background, learning process, achievement, academic record, RPP, and alumni data in SMA Islam Al-Azhar 1 Jakarta. Furthermore, the data will be analyzed to obtain relevant results for research (Nana Syaodih Sukmadinata, 2012: 221).

\section{DISCUSSION}

\section{Learning Strategies}

Learning strategy is a plan of action (sequence of activities) including the use of methods, and the utilization of various resources or strengths in learning that is structured to achieve a particular goal, that is learning objectives (Abdul Majid, 2013: 7). The lesson plan should serve as a basic guiding exercise to achieve the agreed objectives. Because "Learning strategy can be defined as planning which contains a series of activities designed to achieve certain educational goals. Learning strategy is the next step of the process of learning design that is how to get to the learning process (Ali Hamzah and Muhlisrarini, 2014: 140)."

From the description above, it can be seen that the understanding of learning strategies become an important foundation for the implementation of learning. After that determine the strategies used and know the implications of its use that centered on learners in the development of ability and 
creativity. "The use of strategies in learning activities is necessary because It will facilitate the learning process so as to achieve optimal results. Without a good strategy, the learning process can not be directed so that the learning objectives that have been set difficult to achieve optimally, in other words, learning can not take place effectively and efficiently (Made Wena, 2009: 2-3)."

A well-known and well-practiced learning strategy will lead to improvements and facilitate the delivery of materials, and vice versa that if teachers do not understand about learning strategies will lead to static learning and tedious, this can be detrimental to participants Students, the quality of learning, as well as for the teacher itself. So it has become a propriety for every teacher to understand well and correctly will be the learning strategy that will be used. Learning strategy is just one component of a policy that consists of many elements: goal setting, strategic planning, monitoring, knowledge, time management, efficiency, outputs, interest in interest, self-evaluation and development, feedback, etc. (Galina Kavaliauskiene and Ligija Kaminskiene, 2009: 159).

Paradigms and attitudes that consider learning strategy is not an important thing in learning would be less precise thinking. Because, if the assumption that the delivery of material is enough with the usual learning course, then the learning process seems monotonous so that students feel bored with the presentation the teacher delivered the teacher and finally the students can not understand the content lesson.

Effective learning strategies and appropriate functions in addition to providing a good understand and experience for teachers is also a good thing for students knowing. It is reasonable for teachers to always practice themselves and learn to understand the various forms of learning strategies. Especially in this day and age, teachers are required to balance the pattern and development of students in the middle of information and open technology, so that later learning materials remain the best and interesting for the needs of students.

Based on the article Saskatchewan Education in Abdul Majid (2013: 11-12) proposed that the learning strategy is divided into five forms, namely: The first, Direct learning strategy. A teacher-centered strategy, and most often used. In direct learning strategies include lecture methods, didactic questions, explicit teaching, practice, and exam. The arrangement that forms the learning strategy is also called the series of learning activities. "The learning strategy can be defined as planning that contains a series of activities designed to achieve specific educational goals (Wina Sanjaya, 2011: 126)." This strategy is effectively used to extend information and develop skills step by step.

The direct learning strategy is very effective when used to extend the information and knowledge to the students; the teacher will easily prepare expose the material in learning. Judging from the theoretical principle of strategy, the use of direct learning strategies oriented to the learning objectives undertaken by teachers. Measurement and achievement of learning outcomes is a success factor in the selection and use of learning strategies. PAI teachers have mapped and measured the strategies they used in providing Islamic religious lessons in the classroom.

The researchers get the information from PAI teachers that before doing the learning, teachers have predicted the results to be achieved by using appropriate selection strategies in the achievement of the lesson. The learning objectives measured systematically will facilitate the teacher in delivering the learning precisely, well, and conducive.

The second, Indirect learning strategy. Indirect learning strategies emphasize more on the involvement of learners in making observations and hypotheses, while teachers become facilitators who design learning conditions to be fun by engaging all students to actively provide feedback in learning. The 
indirect learning strategy used by PAI teacher on subjects that can be observed in advance by the learner then continued with the presentation of the findings in front of classmates. Students are directed to research and make observations about the source/basis of Islamic law associated with the case/phenomenon that exists. Also, students are directed to make observations on the habits/personality of classmates, family, the environment, searching and recording habits and good and present findings.

An indirect learning strategy is certainly very helpful in understand improving and hone creativity and innovative for students. The involvement of students or participation is one component of learning strategies that can not be left in the learning process. Because with the participation will facilitate the transfer of knowledge from teachers to students. Also, the participation of students will generate high motivation and curiosity to gain more knowledge from the teacher.

The third, Interactive learning strategy. The Strategies are in the form of discussion and sharing among students, with a range of grouping and interactive methods developed, such as class discussions, small group discussions, and group work. Students will understand increase and memory with the discussion and mutual confirmation, also gave birth to fresh ideas in support of the results of exposure done in groups. In other words, that interactive strategy must be maximized with a maximum. "Learning strategy is tactics of teachers in making effective, efficient, and optimize the function and interaction between learners with learning components in a learning activity to achieve the purpose of teaching (Yatim Riyanto, 2012: 132)."

The interactive learning strategies can be developing by forming groups and categorizing sub-subjects that will be discussed by each group. From the presence of a tight discussion and solid will be able to raise the spirit of creativity and innovation in the students themselves. Of course, this is the goal of interactive learning strategies used by each unit of education in learning. Teachers divide students into groups and are given sub-topics, then do the discussion and present it in front of the class.

The fourth, Strategy of learning through experience. A student-centered and activity-oriented strategy. This strategy emphasizes the learning process rather than on the learning outcomes so that teachers can use this strategy either in the classroom with the simulation method or outside the class with the method of observation, the work method for obtaining a general opinion. Students get the general picture, will cause curiosity, search, and discovery of social attitudes about something, especially about understand and practice of Islamic teachings. Students make good observations, and present in the classroom will add to the inherent understanding and cultivation of social effects to practice Islamic teachings starting from themselves.

The fifth, Self-learning strategy. Selfdirected learning strategies aim to build individual initiative, self-study planning by students with the help of teachers. The teacher can measure the extent of the learner's actions in completing the mandate/responsibility given, or the effort aims to train and familiarize learners to live honestly, courageously and responsibly.

The teachers apply self-learning strategies should also be ready to be mentors or facilitators of learning activities. So, the teachers must properly understand the situation, condition, and background of students so that the knowledge gained can also be balanced with the development of interests, talents, and potential. The balancing will produce students who can perform and have high fighting power and hard work in improving his life better. In general, great students, intelligent, and character values are the desire of the nation because he can be an asset as a national leader in the future. 


\section{Research Findings}

Based on findings at SMA Islam AlAzhar 1 Jakarta that Islamic religious teachers organizing various learning strategies to improve the professionalism and quality of teacher learning, as follows:

In the observation of the researcher, the activity of learning in SMA Islam $\mathrm{Al}$ Azhar 1 Jakarta are very conducive and run very well. The teacher's council meeting, support each and always hold evaluation about the development of learning in each class. This kind of activity is a good step that has been done by the council of teachers because it will facilitate in providing information and current developments of learners, learning strategies used and forms of obstacles encountered in learning.

Implementation of learning in SMA Islam Al-Azhar 1 Jakarta always make improvements and developments become more robust and mutually review and correct on learning strategies used by each teacher. Because remembering the development of information and technology easily accessed by students must also be offset by the dexterity of the teacher Council in balancing the subject matter to the needs and desires of students.

Studies on learning strategies are not spared for discussion in training, regular meetings, and mutual requests for input among teachers. Learning activities on improving strategy become an important point in the process of advancing the quality of education, especially the understanding of students. Therefore, activities and learning strategies are an important issue for SMA Islam Al-Azhar 1 Jakarta in realizing a quality learning system.

Leaders of SMA Islam Al-Azhar 1 Jakarta always supervise by persuasive approach both personal and group to improve the closeness and good interaction between the leadership and subordinates for the realization of a shared commitment to achieving the predetermined educational goals. Also, the subordinates (staff and teacher councils) show a mutual remind and brave to provide solutions or suggestions to leaders to create harmonization and a good atmosphere and friendly such as family.

Furthermore, PAI teacher conveys that learning strategy must be done with many variants so that 1 students do not get bored in following each subject matter given. Learning strategy is the most important tool that should be used by teachers in giving the lesson, so it can facilitate the teacher in the process of transfer of knowledge to the students, directing to the same understanding of the intended purpose. By knowing the existing learning strategies, it will increase the ability and competence of teachers in each teaching material that will be given.

The success factor of learning depends on the teacher's understanding of the situation, the condition and the background of the students and the classroom environment so that the choice of learning strategy should be tailored to the teacher's analysis for its success. And, PAI teachers said that the student's response to the subject matter is going well, and the achievement is very high because all students in this excellent school have the high capacity.

PAI teachers use direct learning strategies in general studies and should be shared with students. Because the effectiveness of direct learning strategies is very good when activity centered on teachers, who become more dominant in providing information intact to students. The direct learning strategy is very effective when used to extend the information and knowledge to the students; the teacher will expose the material. And, this is doing by teachers of PAI SMA Islam Al-Azhar 1 Jakarta in providing understanding to students.

Based on information from PAI teachers that before learning, teachers have predicted the outcomes of used appropriate selection strategies in their learning achievement. The learning objectives 
measured systematically will facilitate the teacher in delivering the learning precisely, well, and conducive. PAI teachers have positioned the students as the objects required for active learning, although in direct learning strategies the role of students more listening/observing. However, students must be responses on the delivery of teaching materials from the teacher. These activities will encourage students to move both verbal, psychic, his confidence and mental strength to realize the active and creative students.

Especially, PAI teachers used direct learning strategies in each class by considering the needs and objectives of the lesson set. The use of direct learning strategies must be balanced with understanding the situation and conditions of students and classroom so that the material can be received easily for students. The direct learning strategies are learning by using speech methods, providing didactic questions, giving exercises and demonstrations.

The PAI teachers observed advance for students, then continued used indirect learning strategy on subjects. The subjects include the sources of Islamic law, attitude values, and mazmumah morals. The students directed to research and make observations about the source/basis of Islamic law associated with the case/phenomenon that exists. And, the students directed to make observations on the habits/personality of classmates, family, the environment, searching and recording habits and good presentation of findings.

The PAI teachers of SMA SMA Islam Al-Azhar 1 Jakarta also used interactive learning strategy. The aims to make it easier for teachers to deliver the subject matter. The position of PAI teacher is a facilitator that designs conducive and enjoyable learning conditions. A form of learning is done with involved students to find and confirm knowledge, and conclude it and present the findings in the classroom. This strategy is certainly very helpful in improving understand and hone creativity and innovative in students.

The involvement of students or participation is a component of learning strategies that can not be left in the learning process. Because the participation will facilitate the transfer of knowledge from teachers to learners. And, the participation of students will generate high motivation and curiosity to gain more knowledge from the teacher. In the observation, the educational providers in SMA Islam AlAzhar 1 Jakarta implementing the learning activities very well, they are a team of good that mutually support and advise each other. The activities are seen on the pattern of activities performed by a family who know and conscious with the positions, duties, and responsibilities charged to each.

Researchers confirm to PAI teachers, that the strategy was implemented in the provision of teaching Islamic study. The teacher divides the students in group form, and the group gets sub theme of discussion, then the group is given freedom to express and analyze the sub theme. Once completed, the each group will present the results of the ideas and findings, and the teacher refines each group's exposure at the end. Based on the opinion of PAI teachers "This strategy is the strategy that I use most often because good interaction will facilitate attachment of information and understand to students. I am usually forming groups and invite discussion, mutual inquiry, and conclude.

Also, PAI teachers implemented learning strategies through experiences such as recreation, this is known by the information that all students involved in recreational activities at the end of each semester. The activities are well packed and arranged, which emphasizes aspects of potential development and understanding of subject matter for students. This regulation of recreation is determined based on meetings of school leaders and teacher councils, taking into account various matters, such as duration and location of 
activities, schedules, and materials (potential development) provided to students. All of the points have been well discussed based on the meeting results so that the implementation of learning strategies through experience can take place smoothly, and bring significant changes for students.

The learning strategy through experience can take the observations form useful to get an overview of public opinion. The students get the general picture, so it appears the cause curiosity, search, and discovery of social attitudes. Especially about understand and practice of Islamic teachings. Students make good observations and present in the classroom, That it will add to the inherent understand and cultivation of social effects to practice Islamic starting from themselves.

In his statement, PAI teacher also began to familiarizing for students to the attention of local environmental conditions. This suggestion is conveyed by connecting the community activities around the routine of praying in the mosque. Students must be required to make a report and present it in front of their friends. This advice is part of the learning strategy through experience that students familiarized to observe the situation and phenomena that occur in the vicinity. PAI teacher said this strategy used on the subject matter relating to role prayer and morality karimah.

The PAI teachers applied independent learning strategies that this learning strategy focuses on the seriousness of students in learning. It used to improve knowledge and understand of Islamic studies, which aim as the practice of Islamic role in everyday life. The researcher confirmed to the teacher of PAI that the strategy had been applied in giving the teaching material of Islamic studies.

PAI teacher explained the selflearning strategy had been used related to drikir and Prayer in lessons. Students are gave quotes of drikir and prayer as a form of knowledge and practice of Islamic studies for recitation and home practice. In the observation of researchers, the teacher examined and questioned the reports of assignments given at home. Also, the teacher also asks the students understand in the previous lesson, repeating the lesson at home or new subject that has been known related to the subject Islamic studies. Of course, the efforts made PAI teachers are the right strategy for students to always remember in carrying out the diligent study, diligent, and find the independent learning patterns so able to deliver it to the position of understanding intact.

\section{CONCLUSION}

From the description, it can be concluded that the teacher of PAI SMA Islam Al-Azhar 1 Jakarta can develop the competence of teaching well. The selected learning strategy and used are expected to form a quality student. Also, PAI teachers understood well and practiced learning strategies in delivering their teaching materials by applying variants of learning strategies. The Implementation of strategies is; PAI Teachers use direct learning strategies to facilitate the delivery and conducting the students in the classroom.

The use of the learning strategy becomes a plus for the teacher in giving the best of himself. This direct learning strategy is very appropriate to use in the form of classes with a large number of learners, because the teacher only served as an informer, and the students welcome to inquire on the subject that has not been known.

Indirect Learning Strategy is the teacher provides an opportunity for students to find their own, review themselves, and conclude about the theme of religious education. The students implementing the observation and analysis of results should also be presented in front of the class. And, the each group responding and commenting on the observation work. And, the teacher provides an assessment of the outcomes of students in a short study. 
Interactive Learning Strategy focuses on the student's active in the learning process. Teachers provide subthemes to students divided into small groups first. The each group must be discussed, record, formulate from the elaboration that has been done. After the group completes its tasks, the next step is inviting the groups in turn to present the sub-themes that are the task.

And, Learning Strategies through Experience centered on the activities of students. The teachers focused on learning rather than on results but the process. The learning strategy is done in the form of simulation in the classroom and observation and recreation outside the classroom. Habituation in the process of activity has formed students have high confidence over its potential, and able to display their knowledge in the community, and practiced it in everyday life, as an exemplary start from yourself.

Furthermore, Independent Learning Strategies are giving tasks and exam to students. It is to form the ability to find and good ideas. Therefore, the teachers should use independent learning strategies in the provision of material. This strategy can form students so able to plan ways and models of learning in their style. The ideas and initiatives of students will be honed more strongly with the use of this independent strategy. Of course, the guidance of a teacher to be a supporting factor successful in learning of the education unit.

\section{REFERENCES}

Data KPAI tahun 2014, (www.kpai.go.id) diakses dengan pengambilan data pada tanggal 10 Januari 2014.

Hamzah, Ali dan Muhlisrarini. (2014). Perencanaan dan Strategi Pembelajaran Matematika. Jakarta: PT.RajaGrafindo Persada.

Kavaliauskiene, Galina and Kaminskiene, Ligija. (2009). A complementary approach to lifelong learning strategies. Academic Journal, Issue 18, (Iberica, 2009): 159.

Majid, Abdul. (2013). Strategi Pembelajaran. Bandung: PT Remaja Rosdakarya.

Riyanto, Yatim. (2012). Paradigma Baru Pembelajaran. Jakarta: Kencana.

Sanjaya Wina. (2011). Kurikulum dan Pembelajaran: Teori dan Praktik Pengembangan Kurikulum Tingkat Satuan Pendidikan (KTSP). Jakarta: Kencana.

Sugiyono. 2009. Metode Penelitian pendidikan Kuantitatif, Kualitatif dan R\& D. Bandung: Alfabeta.

Sukmadinata, Nana Syaodih. (2012). Metode Penelitian Pendidikan. Bandung: PT.Remaja Rosdakarya.

S. Margono. (2007). Metodologi Penelitian Pendidikan. Jakarta: PT.Rineka Cipta.

Wena, Made. (2009). Strategi Pembelajaran Inovatif Kontemporer. Jakarta: Bumi Aksara. 